\title{
The Development of Small and Medium Industries in Jember Regency
}

\author{
$1^{\text {st }}$ Budi Hariono \\ Agriculture Technology \\ Politeknik Negeri Jember \\ Jember, Indonesia \\ budihariono1966@gmail.com \\ $4^{\text {th }}$ Saiful Anwar \\ Engineering \\ Politeknik Negeri Jember \\ Jember, Indonesia \\ sanwar2512@yahoo.com
}

\author{
$2^{\text {nd }}$ Rizza Wijaya \\ Agriculture Technology \\ Politeknik Negeri Jember \\ Jember, Indonesia \\ rizza.wijaya@polije.ac.id \\ $5^{\text {th }}$ Bambang Herry Purnomo \\ Agriculture Technology \\ Universitas Jember \\ Jember, Indonesia \\ binauf06@yahoo.com
}

\author{
$3^{\text {rd }}$ Mokhamad Fatoni Kurnianto \\ Agriculture Technology \\ Politeknik Negeri Jember \\ Jember, Indonesia \\ ftnpolije@gmail.com \\ $6^{\text {th }}$ Nanang Dwi Wahyono \\ Agricultural Production \\ Politeknik Negeri Jember \\ Jember, Indonesia \\ nanangdwiw355@gmail.com
}

\begin{abstract}
Jember Regency is one of the economic centers located in East Java. As it is proved that Small and Medium Industries (IKM) grows in this region significantly. The management of the IKM is considered low as it makes the coordination and development of the economy itself difficult. The identification result showed that the sub-district which become the centers of IKM in Jember Regency were Kaliwates, Sumbersari and Patrang. In those regions, the number of SMIs reaches $40.24 \%$ or around 101 units, while the remaining $59.76 \%$ are spread in other districts. Most of SMIs in Jember are in the category of Processing Industry (94\%). The groups of Priority industry in Jember Regency are Rice Milling Industry and Rice Polishing, Bread and Bakery Product Industry, Wooded Building Material Industry, Drinking Water and Mineral Water Industry, and Processed Food Industry.
\end{abstract}

Keywords-Jember District, Small and Medium Industries (IKM), and Priority Industry.

\section{INTRODUCTION}

IKM are business sectors dominating the economic activities of the people in Indonesia. These sectors have become one of the boosters of the national economy, especially after the economic and monetary crisis which hit Indonesia in 1997. IKM are proved to be tough and able to survive and even grow convincingly in this era whereas the other industries are declined. In Indonesia limited facilities and capital is to be made to be the most important . In running the business, IKM utilize business opportunities that arise in community, rely on the surrounding natural resources, operating the appropriate or simple multipurpose technology, detach from any foreign debt, avoids too much debt as the capital is not large enough and some have been export-oriented. Those characteristics then turned out to be the strength for IKM as they last through the occured economic shock. The strength of IKM seems to awaken economic actors and policy makers in this country since this business sector has a strategic role and becomes the basis of the national economy [1]. In Indonesia limited facilities and capital is to be made to be the most important [2].
Regional economic development is an integral part of national development which has the basic objective to actualize the welfare and prosperity of the community. To achieve this goal, the local government and its society have to take the initiative and commit to regional development, be able to assess and use all types of resources in that area to sustainably develop regional economy [2].

IKM are the potential business sectors growing from the initiative and creativity of the local community. These business sectors are able to develop and have large impact on the optimization of resources in the region as well as increasing income and community welfare. Therefore, IKM can be used as a basis in determining the direction/priority of regional economic development. This policy is a description from Presidential Instruction No. 6/2007 which concerns on the Policy for Accelerating the Development of the Real Sector and The Empowerment of Micro, Small and Medium Enterprises (IKM) [3].

Jember Regency is one of the economic growth centers in East Java. The developed industry of this region was dominated by IKM, especially the ones that included in the food and beverage and tobacco industries, as well as the goods made of woods and forest products industry. In 2013, the total number of IKM reached 251 units with total workforce as many as 10.306 people. The total investment value reached 496.42 billion rupiah with production value around 2,980.28 billion rupiah whereas the value of raw and auxiliary materials was 281.35 billion rupiah. This value was lower the one achieved in 2012. Previously, the number of business met 315 units with 10.379 labors. Meanwhile, the total investment value reached 526.43 billion rupiah, with production value around 3,561.69 billion rupiah, while the value of raw and auxiliary materials were into 380.95 billion rupiah.

Generally, the labor force in Jember Regency consists of people who had worked $(59.39 \%)$; job-seekers $(0.93 \%)$; people who want to work if there are jobs provided $(6.36 \%)$; non labor force $(32.64 \%)$. It indicates that the job seekers are 126,809 
people (7.29\%). The development of SMIs in Jember Regency is urgently needed to create a superior industry that is competitive in Jember Regency so that it impacts the improvement of the welfare of the community and the progress of the region. As one of the regencies that has small and medium scale of businesses in East Java, Jember Regency, it requires the details of information on potential profile of IKM and its development priority so that it can be useful as the formulation on the Policy of effective development of IKM in the region [4].

This research aimed at improving the government role effectiveness in developing IKM through the appropriate policy formulation so that has an impact on IKM priority competition and the societies' economic.

\section{RESEARCH METHODOLOGY}

This research was conducted by using logical thinking framework based on strong scientific argumentation. The recommendation as the result of the construction was based on the actual problem and the resolve efforts were gotten by using relevant methodology. The study started by deciding the IKM development priority based on the potency and feature by using Weighted Product Method (WPM) equal to the assessment criteria so that the policy, that would be established, would be focus and effective. The IKM that had been selected as the priority or featured was then analyzed deeply on its features. SWOT analysis was used to develop IKM priority so that created the effective and operational strategy in IKM priority development at Jember regency area. The result of this research would be beneficial for the government, businessmen, and another party as a valuable suggestion in policy formulation to develop IKM beneficially and continually [5].

\section{A. Research Area}

IKM development research at Jember regency was conducted in some districts area at Jember. The district's area that had been selected as the research area was determined by using purposive sampling with consideration that the area was a dominant area for potential IKM activity.

\section{B. Data Collection Method}

The data collected in this research consisted of primary and secondary data. The primary data was collected from field observation and in-depth interview with expert respondents, while the secondary data was collected from the literature review with desk research method.

\section{Analysis Methods}

\section{1) Descriptive Analysis}

Descriptive analysis was done by collecting, analyzing, and presenting the result of the data so that the information about the general characteristic and tendency of the data was collected.

\section{2) Weighted Product Method (WPM)}

The Weighted Product Method is one of the multi decision making techniques or Multi Attribute Decision Making
(MADM). Weighted Product Method, the aggregate value was gotten by multiplying each rating (score) of the criteria on each alternative.

\section{3) SWOT analysis}

The IKM Priority development strategy at Jember regency was formulated by using SWOT analysis.

This technique was used because it has the ability to be comprehensive in solving the problem from some various aspects, internal and external, integrative.

\section{RESULTS AND DISCUSSION}

The continually of a business was a problem that often faced by IKM. This problem appeared because of the existence of some obstacles like low resources, limited market scope, traditional technology, limited business asset, and weak business partnership with other small industries [7].

\section{A. IKM Identification at Jember Regency}

Based on the data gained by The Department of Industry, Trade of Jember regency, it was known that the number of business unit in 2013 was about 251 units or decreased as much as $20.32 \%$ in comparison to 2012 that was 315 units (Fig. 1). The decrease indicated that there still need IKM development in the form of activity programs starting from identification and data collection processes, reinforcement, counseling, evaluation and monitoring the IKM intensively in order to make this business grow and develop continually.

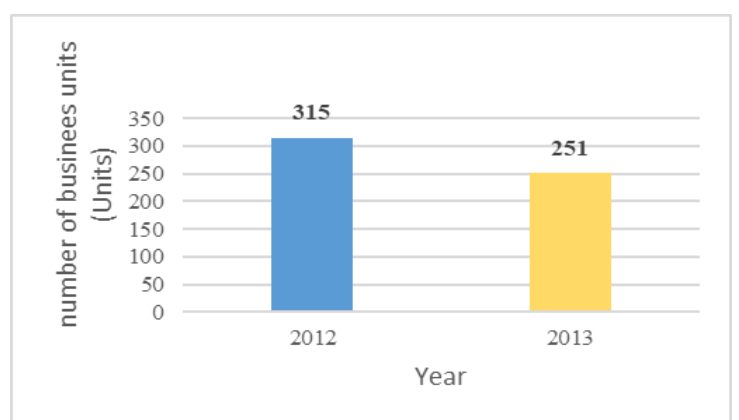

Fig 1. The total number of business unit in 2012 and 2013

The economic value of IKM sector in 2013 was 3.506 billion rupiah or decrease as much as $1.55 \%$ in comparison to 2012 that was 3.562 billion rupiah as seen in Figure 2. scale IKM had the dominant economic contribution rather than small-scale IKM. The contribution of small business to IKM economic value was only $6.18 \%$ or about 216.6 billion rupiah, whereas the contribution of the medium scale IKM reach $93.8 \%$ or 3.289 .81 billion rupiahs. This indicated that medium business had a more big production capacity and product added-value rather than small business. 


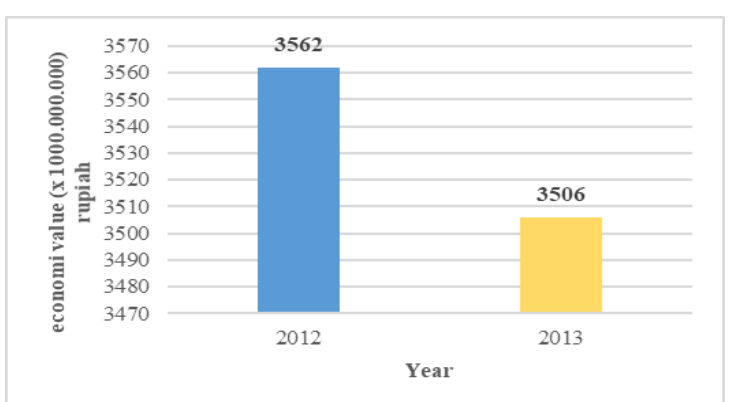

Fig 2. The economic value of IKM sector in 2012 and 2013

\section{B. The types and the Distribution of IKM in Jember Regency}

Most of the IKM in Jember Regency are included in the category of Processing Industry (94\%) and few are included in the category of the Industry of Trade, Repair and Maintenance of Cars and Motorbikes (3.6\%) and the category of Office Administration Services Industry, Office Support Services and Other Business Support Services (2.4\%).

The most dominant type of IKM is the Food Industry category, which is 89 units $(35.6 \%)$, the next is 17 units of Wood \& Cork Industry (7.6\%), and the Beverage Industry as many as 11 units $(6.8 \%)$. Meanwhile, Industry groups whose numbers are less than $2 \%$ of the total number of IKM business units are industries coded 29, 13, 15, 20, 25, 28 and 33. In Table 1, it can be seen the types of IKM and their proportion based on the number of business units in Jember Regency in 2012.

Table 1. The type proportion of IKM based on the units number of business

\begin{tabular}{|c|c|c|}
\hline No. & Basic Group of Industry & $\begin{array}{c}\text { Proportion } \\
(\%)\end{array}$ \\
\hline 1 & Food Industry & 35.6 \\
\hline 2 & Wood \& Cork Industry & 7.6 \\
\hline 3 & Beverage Industry & 6.8 \\
\hline 4 & $\begin{array}{l}\text { Recording Media Reproduction and Printing } \\
\text { Industry }\end{array}$ & 6.8 \\
\hline 5 & Non-Metal Excavation Industry & 6.8 \\
\hline 6 & Furniture Industry & 5.6 \\
\hline 7 & Chemical and Chemical Goods Industry & 4.8 \\
\hline 8 & Tobacco Processing Industry & 4.4 \\
\hline 9 & $\begin{array}{l}\text { Metal Goods Industry, Except Mechinary and } \\
\text { Equipment }\end{array}$ & 3.6 \\
\hline 10 & Other Processing Industry & 3.6 \\
\hline
\end{tabular}

\section{The Priority IKM in Jember Regency}

The priority IKM in Kabupaten Jember are determined based on 8 (eight) key criteria. That are 1) Number of business units; 2) Amount of labor absorption; 3) Value of business investment; 4) Economic value; 5) Potential of raw materials; 6) Mastery of technology; 7) Market potential; and 8) Product uniqueness. Each key criterion has different weight. The weight value describes the degree of importance of each criterion in the process of determining the priority IKM [8].

The districts that have almost identical resource potential have a tendency to have the same priority IKM. The results of the analysis showed that there were only 11 industry groups based on the 3 digit Standard Classification of Indonesian Business Field code (KBLI code) which became the first priority IKM in Jember Regency as shown in Table 2.

For example, the 239 code became the dominant industrial group because it emerged as the first priority IKM in 6 districts that are Arjasa, Bangsalsari, Puger, Sukowono, Sumberjambe and Wuluhan. The priority IKM type consists of various types of businesses, including the processing of stone into coral/fractional stones/building materials IKM. The IKM of fractional stones processing (mill, great, groats), limestone seeds (grid rock, groats, dolomite), limestone and powdered lime, as well as the IKM of red bricks processing, press tiles and wuwung.

The next industry group was the code 107 which is found in 5 districts, that are Jenggawah, Kaliwates, Panti, Patrang, and Sumbersari with the type of business in the form of various snacks processing, starting from dry snacks such as egg beans, pastries, crackers, opaque, fried edamame, various chips to semi-wet snacks such as cakes (bread, brownies).

Table 2. The priority IKM grouping based on the industry group (3 Digit KBLI Code)

\begin{tabular}{|c|c|c|c|}
\hline No. & $\begin{array}{l}\text { The } \\
\text { priority } \\
\text { IKM } \\
\text { Code } \\
\end{array}$ & Districts & $\begin{array}{l}\text { Various Types of } \\
\text { Business }\end{array}$ \\
\hline 1. & 239 & $\begin{array}{l}\text { Arjasa, Bangsalsari, Puger, } \\
\text { Sukowono, Sumberjambe, } \\
\text { and Wuluhan }\end{array}$ & $\begin{array}{l}\text { The IKM that produces } \\
\text { coral/fractional } \\
\text { building } \\
\text { limestones/ } \\
\text { limestone, powdered lime, } \\
\text { red bricks, tiles. }\end{array}$ \\
\hline 2. & 107 & $\begin{array}{l}\text { Jenggawah, Kaliwates, } \\
\text { Panti, Patrang, and } \\
\text { Sumbersari }\end{array}$ & $\begin{array}{l}\text { The IKM that produces } \\
\text { snacks. Such as, egg } \\
\text { beans, pastries, crackers, } \\
\text { cakes (bread, brownies) } \\
\text { opaque, banana chips, } \\
\text { cassava chips, and fried } \\
\text { edamame }\end{array}$ \\
\hline 3. & 120 & $\begin{array}{l}\text { Ajung, Ambulu, Pakusari, } \\
\text { and Sukorambi }\end{array}$ & $\begin{array}{l}\text { The IKM of Na-Oogst } \\
\text { and Voor Oosgt tobacco } \\
\text { drying for the } \\
\text { manufacture of cigar and } \\
\text { cigarettes, and the } \\
\text { chopped tobacco } \\
\text { processing }\end{array}$ \\
\hline 4. & 162 & Mayang, Tanggul, and Silo & $\begin{array}{l}\text { The IKM that produces } \\
\text { balken albasia, sill, door, } \\
\text { shutter, chair, cupboard, } \\
\text { buffet, veneer and sawn } \\
\text { timber }\end{array}$ \\
\hline 5. & 329 & Balung & $\begin{array}{l}\text { The IKM of Handy craft } \\
\text { IKM produces rosary, } \\
\text { necklace, ring, bracelet, } \\
\text { cigarette pipe, stick, wood } \\
\text { plate and ashtray }\end{array}$ \\
\hline 6. & 201 & Gumuk Mas & $\begin{array}{l}\text { The IKM that produces } \\
\text { organic } \\
\text { granular }\end{array}$ \\
\hline 7. & 210 & Jelbuk & $\begin{array}{l}\text { The IKM that produces } \\
\text { herbal/traditional potion } \\
\text { such as black cumin } \\
\text { capsule, white turmeric } \\
\text { and so on }\end{array}$ \\
\hline 8. & 259 & Mumbulsari & $\begin{array}{l}\text { The IKM that produces } \\
\text { iron rack }\end{array}$ \\
\hline
\end{tabular}




\section{Development Strategy of IKM}

The priority IKM development strategy was presented in the form of SWOT matrix. This matrix was used to describe clearly how the possibility and external threat faced could be adjusted with the strengths and weaknesses they had.

The priority IKM which had been selected in each district needed a development strategy to produce competitive products, won the market competition, as well as were able to operate sustainably. Therefore, there were several important strategies to make that happened. The strategies implemented to develop the priority IKM in Jember Regency, as follows: 1) Developing the priority IKM cluster; and 2) Developing the training system to foster an entrepreneurial spirit for the development of the priority competitive IKM; 3) Establishing the investment development system and promotion of the priority IKM via online; 4) Developing the training system and improving the quality and IKM product safety; and 5) Developing the innovation system for the improvement of unique and prospective priority IKM products.

\section{CONCLUSION}

1. IKM in Jember Regency had a big potential to be developed into a strategic industry.

2. The districts which became the center of IKM areas in Jember Regency were Kaliwates, Sumbersari, and Patrang.

3. Most of the IKM in Jember Regency were categorized into Processed Industry.

4. The strategy to develop the priority IKM in Jember Regency was done by improving the priority cluster, training system, innovation and promotion systems, and product innovation system.

\section{ACKNOWLEDGMENT}

This research was supported by Jember Regency Government. We thank our colleagues from Politeknik Negeri Jember who provided insight and expertise that greatly assisted the research.

\section{REFERENCES}

[1] M. Kuncoro, T. Widodo, and R. H. McLeod, "Survey of recent developments," Bull. Indones. Econ. Stud., vol. 45, no. 2, pp. 151176, 2009.

[2] N. D. Wahyono and M. M. D. Utami, "A Review of the Poultry Meat Production Industry for Food Safety in Indonesia," in Journal of Physics: Conference Series, 2018, vol. 953, no. 1, p. 12125.

[3] Rahmana, Iriani, and Oktarina, "Development Strategy for Small and Medium Industries in the Manufacturing Industry Sector," Journal of Industrial Engineering, vol. 13, pp. 1: 14-21, 2012.

[4] R. Nurcahyo, Farizal, E. Setiadi, and Saparudin, "Determination and Development of Core Competencies in Bekasi Regency," Journal of Industrial Engineering, vol. 13, pp. 37-42, 2012.

[5] R. Patrisina and B. Harma, "Analysis of Technical and Financial Aspects of Establishment of Distribution Center for One Village One Product Program (OVOP): Case Study of Embroidery / Embroidered Agam," Journal of Industrial Engineering, vol. 9, pp. $1-24,2011$

[6] Sulistyastuti and Ratih, "Dynamics of Small and Medium Industries Analysis of Regional Concentration of IKM in Indonesia 1999 2001," Journal of Development Economics, vol. 9, 2004.

M. Triharini, D. Larasati, and R. Susanto, "One Village One Product Approach (OVOP) to Develop Regional Craft Potential: Case Study of Pottery Crafts in Plered District," vol. 6, ed. Purwakarta Regency: J.Vis. Art \& Des, 2012, pp. 28-41.

Wiyadi, "Measurement of Small and Medium Industries Competitiveness Index (IKM) in Central Java," Journal of Business Strategy, vol. 13, pp. 77-92, 2009. 